This item was submitted to Loughborough's Research Repository by the author.

Items in Figshare are protected by copyright, with all rights reserved, unless otherwise indicated.

\title{
Mapping coupled open innovation processes from activity theory framework
}

\section{PLEASE CITE THE PUBLISHED VERSION}

http://designmanagementacademy.com/dma2017/

\section{PUBLISHER}

Design Management Academy

\section{VERSION}

AM (Accepted Manuscript)

\section{PUBLISHER STATEMENT}

This work is made available according to the conditions of the Creative Commons Attribution-NonCommercialNoDerivatives 4.0 International (CC BY-NC-ND 4.0) licence. Full details of this licence are available at: https://creativecommons.org/licenses/by-nc-nd/4.0/

\section{LICENCE}

CC BY-NC-ND 4.0

\section{REPOSITORY RECORD}

Canik, Yasemin, Erik Bohemia, and Ida Telalbasic. 2019. "Mapping Coupled Open Innovation Processes from Activity Theory Framework". figshare. https://hdl.handle.net/2134/24922. 


\title{
Mapping coupled open innovation processes from Activity Theory framework
}

\author{
CANIK Yasemin*; BOHEMIA Erik and TELALBASIC Ida \\ Loughborough University London \\ * Corresponding author: y.canik@lboro.ac.uk \\ Paper number: 75
}

\begin{abstract}
Organisations have started to adopt open innovation processes to supplement their internal competencies and resources. Adoption of these processes assist them in keeping up with the pace of technology and protecting their competitive advantage in the market. Despite the significance of open innovation processes, there are few studies focusing on them. The purpose of this study is mapping coupled open innovation processes to contribute to the field of open innovation. The case study research was set up to explore how organisations undertake coupled open innovation processes from the perspective of employees working in a smallmedium sized enterprise. The Activity Theory was used as a research framework. The research findings revealed how the importing and exporting mechanisms of coupled processes. The findings are discussed to fill the knowledge gaps in the existing literature and help design management academia and practice identify future work areas.
\end{abstract}

keywords: design management, coupled processes, activity theory; SME

\section{Introduction}

The concept of open innovation has drawn attention by researchers of innovation studies, such as Chesbrough, Vanhaverbeke \& West (2006), Enkel, Gassmann \& Chesbrough (2009), Gassmann (2006) and Huizingh (2011). It is an overarching umbrella to cluster trends of innovation studies (Huizingh, 2011). From a practical perspective, it enables organisations to protect their competitive advantage (Enkel et al., 2009) and adapt themselves to the changes in the market (Chesbrough, 2003). Despite these significances: 
The field of open innovation is still at an early stage; it offers a wide field in which academics, practitioners and policy makers can be active.

(Gassmann, Enkel \& Chesbrough, 2010, p. 7)

This paper will aim to explore the following points to contribute to the field:

- mapping how organisations undertake coupled open innovation processes from the perspective of employees working in a small-medium sized enterprise (SME)

- identifying future work areas for design management literature and practice

To address the above points, we will explore the open innovation processes in organisations and identify the potential areas for design management research and practice. We have selected a case study research method and Activity Theory (AT) evaluation framework.

First, we will review the literature on open innovation in organisations. Then, we will introduce the case study, which will be followed by discussion and recommendations for further research.

\section{Open innovation in organisations}

Henry Chesbrough introduced the concept of open innovation in 2003. Chesbrough (2003) points out that organisations cannot have all the internal resources to innovate because of the changes in the industry as he called those changes erosion factors.

These erosion factors, such as increased mobility of workers, more capable universities, declining US hegemony, and growing access of start-up firms to venture capital, changed the conditions under which firms innovate (Chesbrough \& Bogers, 2014, p. 16).

Since Chesbrough (2003) introduced the open innovation model to overcome the erosion factors, more researchers, such as Chesbrough \& Appleyard (2007), Chesbrough, Vanhaverbeke \& West (2014), Dodgson, Gann, \& Salter (2006) and Enkel et al. (2009) have further explored this model. Chesbrough \& Bogers (2014) defined of the open innovation model as:

... a distributed innovation process based on purposefully managed knowledge flows across organisational boundaries, using pecuniary and non-pecuniary mechanisms in line with the organisation's business model (p. 17).

The innovation in the above definition, is understood as "the development and commercialisation of new products, processes or services" (Chesbrough \& Bogers, 2014, p. 17). The pecuniary mechanisms involve monetary activities as acquiring and selling; nonpecuniary mechanisms cover social activities as sourcing and revealing (Dahlander \& Gann, 2010). Because these mechanisms are deployed via knowledge flows, it is vital to understand how knowledge flows work. Gassmann \& Enkel (2004) entitle the knowledge flows under three main concepts: i) outside-in process, ii) inside-out process and iii) coupled process (see Figure 1). 


\section{Outside-in process}

In this process, organisations integrate external sources in their innovation process. This can be done via acquiring (pecuniary) and sourcing (non-pecuniary) (Dahlander \& Gann, 2010) as well as obtaining, integrating and commercialising (West $\&$ Bogers, 2014). Gassmann \& Enkel (2004) defines this process as:

Enriching the company's own knowledge base through the integration of suppliers, customers and external knowledge sourcing can increase a company's innovativeness (p. 6).

\section{Inside-out process}

This process enables organisations to profit from unused innovations through exploitation so other organisations utilise them via their business models (Chesbrough $\&$ Bogers, 2014). It also allows innovation to reach the market faster than internal Research \& Development (R\&D) commercialisation (Enkel et al., 2009; Gassmann \& Enkel, 2004). This process is defined as:

Earning profits by bringing ideas to market, selling IP and multiplying technology by transferring ideas to the outside environment (Gassmann \& Enkel, 2004, p. 6).

\section{Coupled process}

Organisations adopting this process co-create together via alliances, cooperation and joint ventures that the purpose is developing and commercialising innovation (Enkel et al., 2009). The definition of this process is:

Coupling the outside-in and inside-out processes by working in alliances with complementary partners in which give and take is crucial for success (Gassmann \& Enkel, 2004, p. 6).

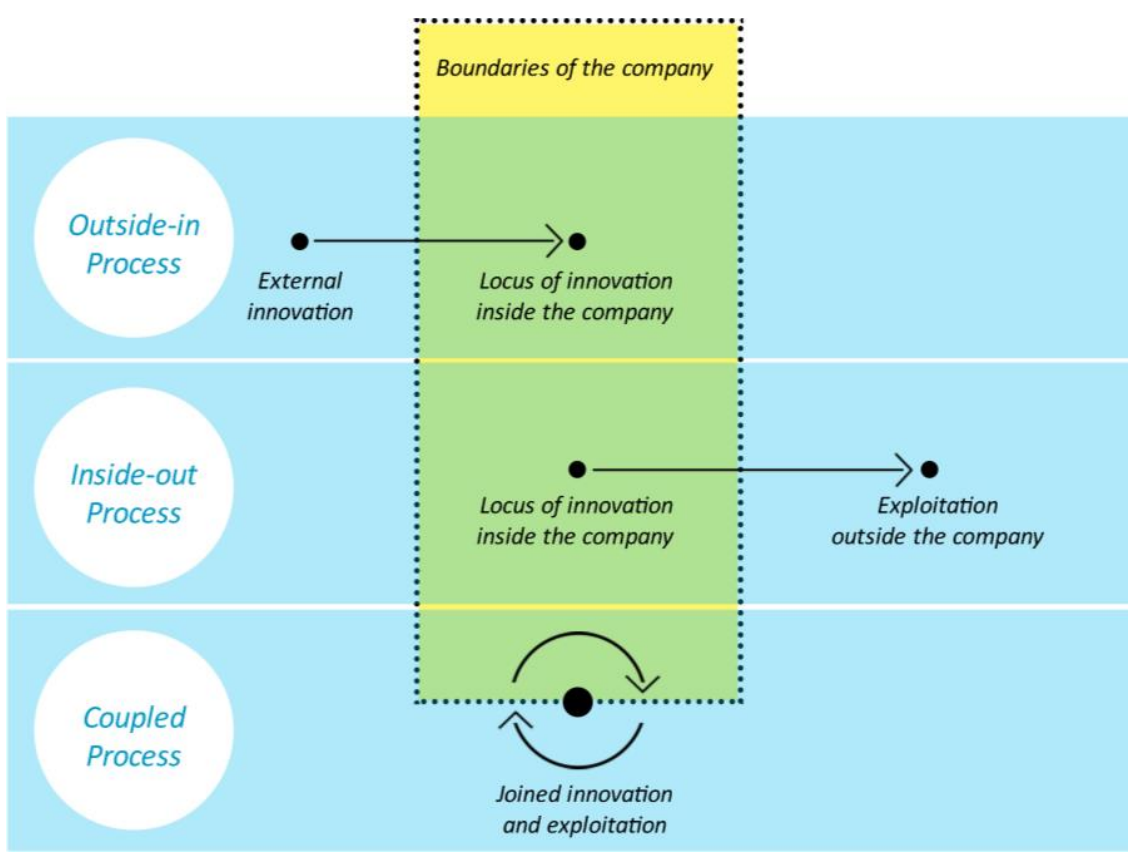

Figure 1 Open innovation processes. source: Gassmann \& Enkel (2004, p.6) 
Piller \& West (2014) suggest an interactive approach towards coupled process. They emphasise the collaboration between organisations and individuals to innovate. They base their research on the open innovation study of Gassmann \& Enkel (2004), user innovation studies of von Hippel $(1988,2005,2010)$ and co-creation studies of Normann \& Ramirez (1992) and Wikström (1996). In regards to their definition, user innovation is a collaboration between organisations and users whom the knowledge is obtained to generate solutions for public good; whilst co-creation is:

an active, creative and collaborative process between a firm and individuals during a product/service development process in which participants contribute to a task initiated and facilitated by the firm (Piller \& West, 2014, p. 39).

Piller \& West (2014) suggest that coupled processes have various dimensions. There are: i) external actor ii) coupling topology iii) impetus for collaboration, and iv) locus of innovation (see Table 1). Piller \& West (2014) explain these dimensions as following:

- External actors, such as customers, universities, research labs, vary regarding the stage of innovation process, such as R\&D stage and commercialisation stage. Furthermore, different actors can affect the outcome of the incentives, coordination and governance of the process.

- The topology of relationship has three forms. These are: i) dyadic, ii) network and iii) community with dyadic relationship being most common one.

- Impetus for collaboration can be top-down and bottom-up.

- Locus of innovation can be between two parties (bi-directional) where innovation occurs internally or multiple parties (interactive) where innovation occurs outside the organisations.

Table 1 Multiple Dimensions of coupled open innovation processes source: Piller \& West, 2014

\begin{tabular}{ll}
\hline Dimensions & Alternatives \\
\hline External Actor & Firms: customer, supplier, complementor, rival \\
& Other organisations: university, research lab, government, \\
& other non-profit organisations \\
& Individual: customer, user, inventor, citizen \\
\hline Coupling Topology & Dyadic: single partner \\
& Network: multiple partners \\
& Community: a new inter-organisational activity \\
\hline Impetus for Collaboration & Top-down: initiated by the upper management \\
& Bottom-up: developed through employee or customer \\
& collaborations \\
\hline Locus of Innovation & Bidirectional: innovation created within organisation \\
& Interactive: innovation jointly created outside the \\
& organisation \\
\hline
\end{tabular}


To implement these processes, researchers suggest different stage models (Cooper, 2008; Piller \& West, 2014). The study of Van der Meer (2007) introduces three innovation stages: i) the concept stage (to invent the ideas), ii) the development stage (to convert the ideas to the project) and iii) the business stage (to transform projects to new business) and these stages are based on the open innovation Stage-Gate model of Cooper (2008). Piller \& West (2014) propose a different process model clustered into four stages: i) defining, ii) finding participants, iii) collaborating, and iv) leveraging. Their study outlines the current-state of these stages and highlights that organisations mostly fail to commercialise in the leveraging stage. The key activities regarding each stage are listed in Table 2.

Table 2 A process model for open innovation processes source: Piller \& West, 2014

\begin{tabular}{ll}
\hline Process Stage & Key Activities \\
\hline Defining & Problem formulation \\
& Institutions and rules: including contract terms, IP \\
& Resource allocation and strategic commitment \\
\hline Finding Participant & Identifying participants with right characteristics \\
& Motivating and retaining a critical mass of collaborators \\
& Selecting the right participants \\
\hline Collaborating & Governance of the collaboration process: organising, \\
& monitoring \\
& Interaction platforms and other tools \\
& Openness of firm attitudes, structure and processes \\
\hline Leveraging & Integrating external knowledge \\
& Commercialising the knowledge through product and \\
& services \\
\hline
\end{tabular}

Although, the studies of Van der Meer (2007) and Piller \& West (2014) lay foundations for understanding coupled processes, still, Piller \& West (2014) emphasise the need for further studies. They recommend that further studies can investigate the coupled processes from the perspective of employees to understand what happens inside the organisations. Therefore, this study focuses on the perception of employees regarding how their organisations undertake coupled processes.

In addition to previous studies (e.g. Van der Meer, 2007; Piller \& West, 2014), this study will divide coupled processes into two mechanisms: i) importing mechanisms (acquiring external knowledge and sources into organisation) and ii) exporting mechanisms (exporting internal knowledge and sources to outside of the organisation). These mechanisms will be explored within a case of an Innovation Institute. An outcome of this study has a potential to help design management academia and practice identify the future research areas.

\section{The case study to explore open innovation in organisations}

We have selected the case study organisation regarding its relevance to explore coupled processes. Before deciding the organisation, we have investigated different types of 
organisations that adopt coupled processes. Potential case study organisations were research institutes, SMEs, universities, suppliers and end users. Among them, we have selected research institutes because of following reasons:

- They can be considered common partners of coupled processes that they partner with universities, suppliers, other research institutes, competitors and end users.

- Our insight was that they might have good balance to import and export knowledge throughout innovation process and the focus of this case study is investigating importing and exporting mechanisms of coupled processes.

The research institute chosen for this case study is based in East London and we will refer to this organisation as East London Innovation Institute (ELII) throughout the paper. The institute was selected for the following reasons:

- ELII jointly collaborates with universities, suppliers, end users and other research institutes to work on Research \& Development (R\&D) manufacturing projects of the automotive sector. This makes them a suitable case for this research as it can be inferred that they adopt coupled processes of open innovation.

- ELII believes that their innovation derives from collaboration and they import and export knowledge to manage their purpose. As this research aims to understand importing and exporting mechanisms distinctively, this makes ELII an appropriate case for this study.

- One of the authors of this paper worked as an intern in the organisation throughout her Master's dissertation process. This had allowed her to intimately understand the organisation structure.

- There was a time limitation during the dissertation period and ELII was the most accessible research institute because of their existing collaboration with Loughborough University.

\section{Research framework: Activity Theory}

As stated above, one main concern of this paper is to have a comprehensive analysis of the phenomenon. We have chosen Activity Theory (AT) and we will explain the theory and its relevance with this study in this part.

What is Activity Theory?

Activity theory (AT) (Engeström, 1987) has its roots in the studies of Marx and Engels and Vygotsky, Leont'ev and Luria (Engeström, Miettinen \& Punamäki, 1999). Waycott, Jones \& Scanlon (2005) define the theory as "a collection of broadly defined concepts that are open to interpretation" (p. 111).

In AT, see Figure 2, an activity is a unit of analysis and provides "the dialectic relationship between subject and object" (Vygotsky, 1978) incorporating these related elements: instruments, rules, community, and division of labour (Engeström ${ }_{L} 1987$ ). 


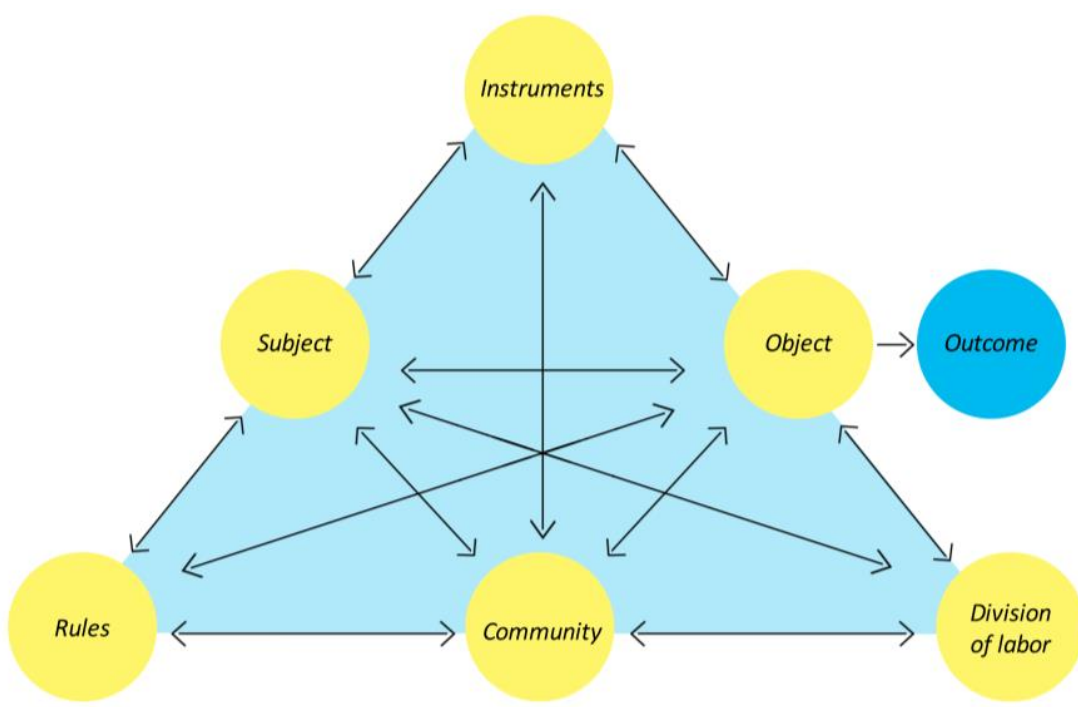

Figure 2 Activity Theory Model source: Engeström (1987, p. 136)

Engeström (1993) defines AT characters as following:

- Object: "the 'raw material' or 'problem space' at which the activity is directed and which is moulded or transformed into outcome" (p. 67)

- Subject: "the individual or subgroup whose agency is chosen as the point of view in the analysis" (p. 67)

- Community: "multiple individuals and/or subgroups who share the same general object" (p. 67)

- Instruments: "physical and symbolic, external and internal tools (mediating instruments and signs)" (p. 67)

- Division of labour: "both the horizontal division of tasks between the members of the community and to the vertical division of power and status" (p. 67)

- Rules: "the explicit and implicit regulations, norms and conventions that constrain actions and interactions within the activity system" (p. 67)

The relevance of Activity Theory with this research

AT is significant for this research because of three main reasons. We will explain these reasons in this part.

Firstly, Hasan \& Kazlauskas (2014) state that AT is all about "who is doing what, why and how" (p. 9). Moreover, Huizingh (2011) emphasises that:

Open innovation requires managers to make new decisions in developing and exploiting innovation activities. When, how, with whom, with what purpose, and in what way should they cooperate with outside parties? ( $p$.

6)

We think that we can generate comprehensive research questions based on the study of Hasan \& Kazlauskas (2014) and Huizingh (2011). For example, we can ask participants who the collaborators are, or with what purpose their organisation collaborates with them.

Secondly, organisations have a level of obscurity including formal and informal interactions in the innovation process (King \& Ockels, 2009). For example, employees in 
the process can also create tacit solutions for their daily work problems that might lead to innovation (Macpherson \& Clark, 2009). Similarly, Cash, Hicks \& Culley (2015) emphasise the significance of AT to analyse 'unconscious' data. Therefore, AT can help us reveal the obscure part of the process.

Finally, AT is a significant framework for observations and interviews to observe complex environments (e.g. modern workplaces) (Cash et al., 2015; Hasan \& Kazlauskas, 2014). It allows researchers to make a multi-dimensional analysis (Cash et al., 2015; Hasan \& Kazlauskas, 2014). Our research is complex because we want to observe the importing and exporting mechanisms of innovation and AT characters can allow us to have a clear mapping of the process.

\section{The Case Study Methodology}

\section{The Research Design}

The main purpose of this study is distinctively analysing importing and exporting mechanisms in coupled processes from the perspective of employees. We have determined two main research questions to investigate in the case of ELII:

- Research Question 1: How are importing mechanisms undertaken in joint R\&D projects?

- Research Question 2: How are exporting mechanisms undertaken in joint R\&D projects?

We have investigated these research questions through semi-structured interviews divided into question and card sessions. We will explain why and how we conducted semistructured question and card session in this part.

To begin, semi-structured interview is a flexible research method that researcher makes a conversation with participant by using pre-prepared questions, but researcher might ask follow-up questions to participants in need (Fylan, 2005). We have selected this method because this method allows researcher "to delve deeply into a topic and to understand thoroughly the answers provided" (Harrell \& Bradley, 2009, p. 27). Furthermore, Barriball $\&$ While (1994) state that this method is useful to observe complex phenomenon with confidential information like this case study.

We have generated research questions based on AT. The study of Hasan \& Kazlauskas (2014) and Huizingh (2011) have guided us to design research questions, such as who, what, what purpose. We have listed these questions in Table 3.

Table 3 Semi-structured Interview Questions based on AT categories

\begin{tabular}{ll}
\hline Activity Category & Semi-structured interview questions \\
\hline Object & $\begin{array}{l}\text { Could you select a project that you have collaborated with } \\
\text { your partners? What is this joint R\&D project about? }\end{array}$ \\
\hline Subject & $\begin{array}{l}\text { Which employees did you work with? What was their role in } \\
\text { the project? }\end{array}$ \\
\hline Community & $\begin{array}{l}\text { Which organisations did you collaborate for this project? } \\
\text { What was the role of each organisation in the project? }\end{array}$ \\
\hline
\end{tabular}




\begin{tabular}{ll}
\hline Division of Labour & How was the division of labour between organisations? \\
\hline Instruments & Which instruments/tools did you use throughout the \\
& project? In which way, did you use them? \\
\hline Rules & $\begin{array}{l}\text { Which rules did you follow throughout the process? In } \\
\text { which way, did you follow them? }\end{array}$ \\
\hline Outcome & With what purpose, did you develop this project? \\
\hline
\end{tabular}

In the card session, we have used a card sorting technique that has helped us map whether AT characters are imported or exported. This technique is a data collection method that is used in interviews to find out the mental model of interviewee who categorizes concepts from their existing knowledge (Daniels, De Chernatony \& Johnson, 1995). The reasons to choose this technique are:

- It is efficient to understand the mental model of interviewees in complex environments (Daniels et al., 1995).

- The study of Chatzakis (2015) demonstrates the efficiency of cards when observing innovation activities in a short time.

- It provides flexibility to the interviewees, who can sort concepts from their existing knowledge by using visual cards (Gammack, 1987).

We have also designed the cards based on AT. As the unit of analysis maps the relationship between object and subject, we have designed object and subject cards to understand the relationship between object and subjects and the direction of the activity (importing or exporting). Figure 3 illustrates the subject cards to represent employees and partners of ELII. Object cards are designed in a way that participants can write the objective and duration of the innovation activity (See Figure 4).
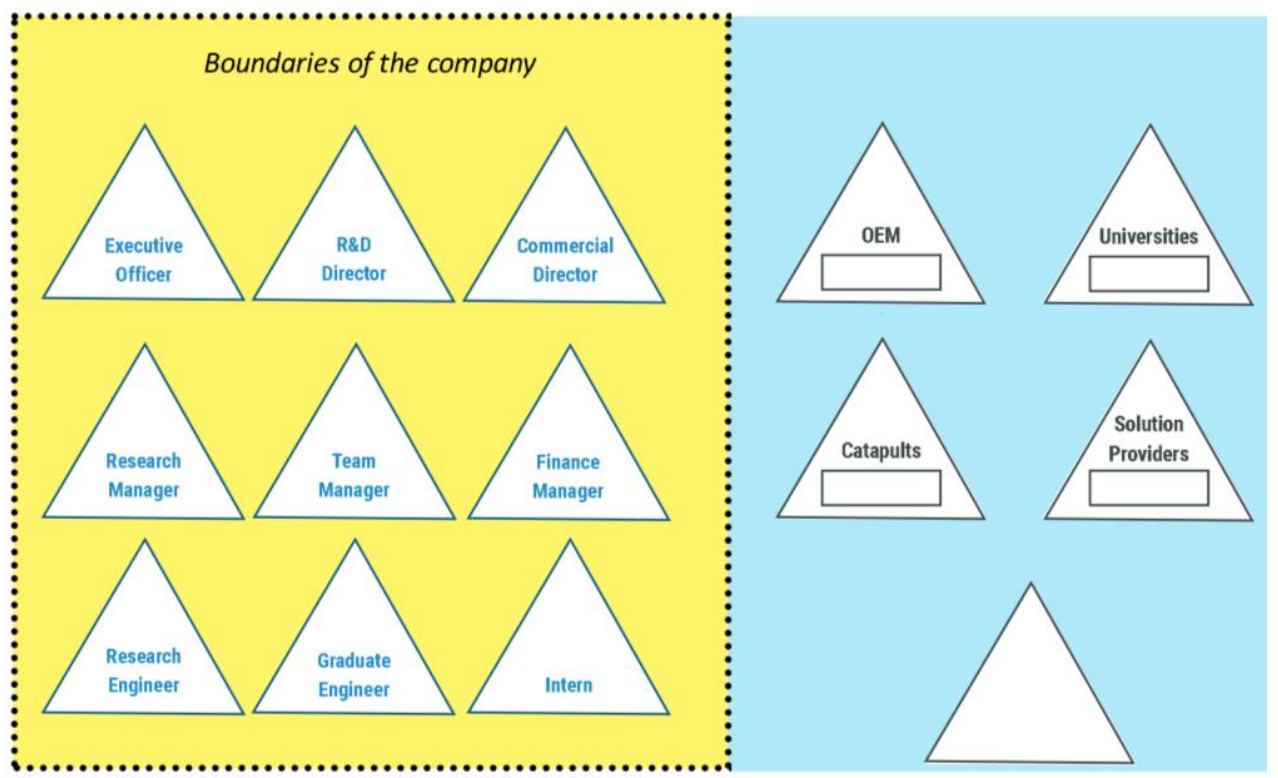

Figure 3 Subject cards used in card session 


\section{Activity:}

\section{Duration:}

\section{Activity:}

\section{Duration:}

\section{Figure 4 Object cards}

\section{The Research}

Eight key employees from ELII participated on the research. They were identified via snowball sampling method (See Figure 5). The research started with question session and ended with card session.
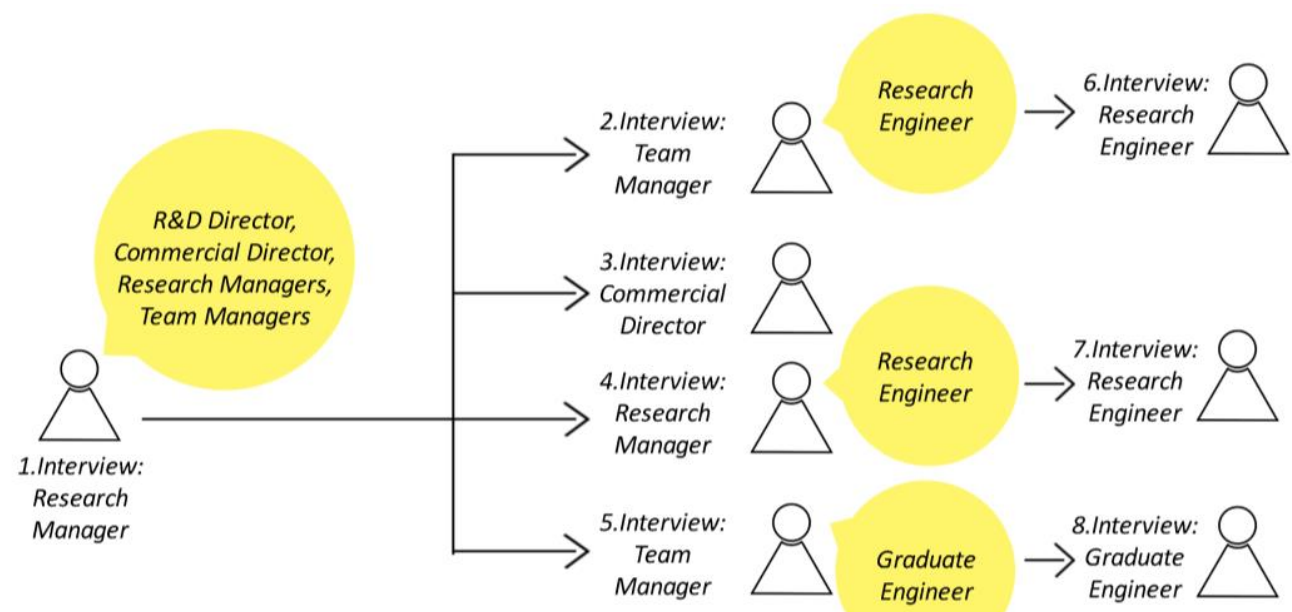

Figure 5 The usage of snowball sampling method

In the question session, participants replied to the AT questions, which are introduced in the previous part (see Table 3 ). In the card session, i) the researcher summarised the question session to a participant by placing visual cards to the board and then ii) the researcher and participant drew lines between the placed cards. The aim of this exercise was to map the roles of participants in the project and their relationship with other participants and activities to understand how they import and export knowledge. Besides, question session is summarised that had allowed researcher and participants to cross check the answers (see Figure 6). 


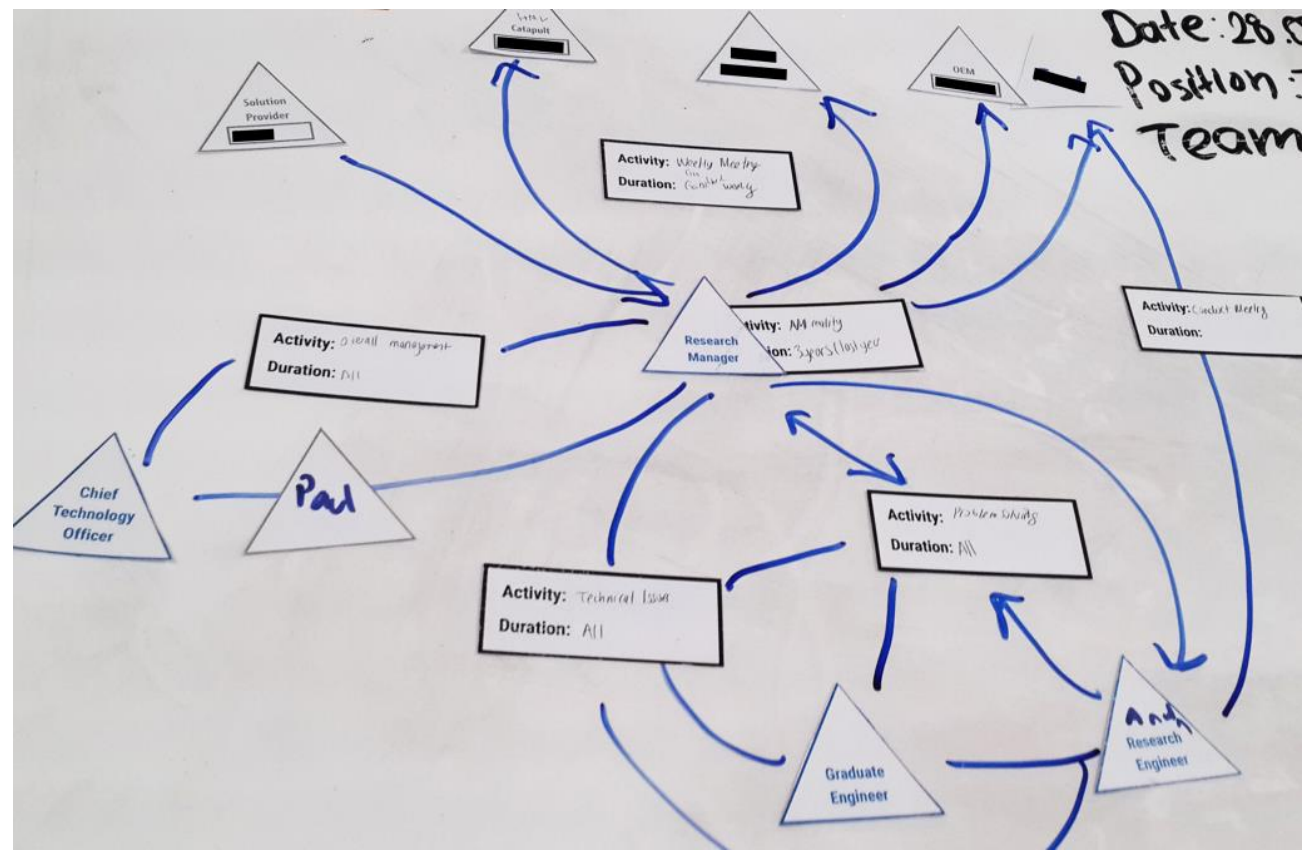

Figure 5 An example of end of the card session board with one of the interviewee (some of the cards text was blanked out to preserve anonymity)

To analyse the data, we have initially transcribed the answers of interview questions and coded these using NVivo. We have coded those answers into activity characters: object, subject, community, division of labour, rules, instruments and outcome. Moreover, we have used photos taken during the card sessions to understand whether activity character is imported or exported (see Figure 5). Table 4 summarises the data analysis.

Table 4 Analysis of research questions

\begin{tabular}{ll}
\hline Question Category & Analysis \\
\hline $\begin{array}{l}\text { Object } \\
\text { hauld you select a project that you } \\
\text { partners? What is this joint R\&D } \\
\text { project about? }\end{array}$ & $\begin{array}{l}\text { As they have work on R\&D projects, we make } \\
\text { sure the objective of the project is importing } \\
\text { ideas to export R\&D projects as Van der Meer } \\
(2007) \text { suggests. }\end{array}$ \\
\hline $\begin{array}{l}\text { Subject } \\
\begin{array}{l}\text { Which employees did you work } \\
\text { with? What was their role in the } \\
\text { project? }\end{array}\end{array}$ & $\begin{array}{l}\text { As we have interviewed with employees of ELII, } \\
\text { we have identified them as subjects of the } \\
\text { project. Based on their role in the organisations } \\
\text { and pictures of card session, we have decided } \\
\text { whether they import or export knowledge. }\end{array}$ \\
\hline $\begin{array}{l}\text { Community } \\
\text { Which organisations did you } \\
\text { collaborate for this project? What } \\
\text { was the role of each organisation in } \\
\text { the project? }\end{array}$ & $\begin{array}{l}\text { Based on the role of the organisations in the } \\
\text { project and card session, we have decided } \\
\text { whether they are part of importing or exporting } \\
\text { community. }\end{array}$ \\
\hline \begin{tabular}{l} 
Division of Labour \\
\hline
\end{tabular} & \begin{tabular}{l} 
We analysed the answers whether there is any \\
\hline
\end{tabular}
\end{tabular}




\begin{tabular}{ll}
\hline $\begin{array}{l}\text { How was the division of labour } \\
\text { between organisations? }\end{array}$ & $\begin{array}{l}\text { hierarchical relationship between organisations } \\
\text { to decide whether there is a bottom-up or top- } \\
\text { down division of labour. }\end{array}$ \\
\hline $\begin{array}{l}\text { Instruments } \\
\text { Which instruments/tools did you use } \\
\text { throughout the project? In which } \\
\text { way, did you use them? }\end{array}$ & $\begin{array}{l}\text { To detect importing and exporting instruments, } \\
\text { rules and outcome, we have followed the same } \\
\text { procedure that we introduced in previous } \\
\text { Rules } \\
\text { Which rules did you follow } \\
\text { throughout the process? In which } \\
\text { way, did you follow them? } \\
\text { Outcome } \\
\text { With what purpose, did you develop } \\
\text { this project? }\end{array}$ \\
\hline
\end{tabular}

\section{The Research Findings}

We have summarised the case study findings revealing how importing and exporting mechanisms are undertaken in joint R\&D projects in Table 5.

Table 5 How importing and exporting mechanisms are undertaken in joint R\&D projects

\begin{tabular}{lll}
\hline & Importing & Exporting \\
\hline Object & Ideas & R\&D Projects \\
\hline Subject & Engineers in ELII & Managers in ELII \\
\hline Community & Suppliers & Research institutes \\
& Universities & SMEs \\
& Public and & Universities \\
& government funding & \\
bodies & Users & \\
\hline Division of labour & Bottom-up division & Bottom-up division of \\
& of labour & labour \\
& & \\
& & \\
\hline Instruments & Research tools (e.g. & Reports \\
& CAD software, & Presentations \\
& technical equipment) & Posters \\
& Manufacturing & Videos \\
& Resources (e.g. & Prototypes \\
& factory, funding, \\
prototyping tools) & \\
\hline & &
\end{tabular}




\begin{tabular}{lll}
\hline Rules & $\begin{array}{l}\text { Timeframe } \\
\text { and funding }\end{array}$ & Contracts \\
\hline Outcome & Technical sources & Technical sources and \\
& and knowledge & knowledge (e.g. \\
& New resources & intellectual property) \\
& New partnerships & Business growth \\
& Competitive & Innovation \\
& advantage & \\
Leadership & \\
\hline
\end{tabular}

The analysis outlines the joint R\&D projects in terms of seven AT categories. We will explain the research findings for each category in this part.

To begin, the main objective of this study was investigating the process of importing ideas to export R\&D projects. Therefore, all projects introduced by participants covers this process.

Main subjects are engineers and managers working for ELII. Whilst engineers import their knowledge to the process, one main responsibility of managers is to export the imported knowledge to the partners.

Regarding community, suppliers (e.g. resources), clients (e.g. prototyping tools), universities (e.g. research area), public and government funding bodies (e.g. funding) import their knowledge and sources to these projects. On the other hand, private and public research institutes, SMEs and universities (e.g. Ph.D. projects) export their knowledge and sources throughout this process.

As a division of labour, bottom-up division of labour is followed by organisations because there is no hierarchical difference between partners. Participants also explained how the process is undertaken by employees and partners in terms of division of labour. The projects are given to project managers (e.g. research engineers or managers of the organisations or multiple managers from different partners) and they have the full responsibility from the beginning to the end. They follow the Stage-Gate model that is divided into following steps: defining the research problem, setting up the project members (consortium), developing the project (collaboration process) and commercialising it. In the beginning of the project, the research problem is identified and rules (e.g. IP, contracts, project timeline) and resources are defined based on the problem. Afterwards, project managers identify which partners are required for the project. After selecting the participants, collaboration process starts. Each member to update members and exchange knowledge. At the end of the project, the ideal scenario is commercialising these projects via spin-off venture companies and IP strategies. However, in this case study, participants state that they fail to commercialise most of the joint R\&D projects. Although they have the intellectual property rights of these projects, they do not know how to profit from them.

Instruments vary based the requirements of these projects. In general, organisations need research tools (e.g. CAD software, technical equipment) and manufacturing resources (e.g. prototyping tools, factory, funding) that they import from suppliers, clients and universities. By using these tools, they export reports (e.g. feasibility reports), presentations, posters, videos and prototypes to explain the outcome of these projects. 
Rules are generally set up in the beginning of the project as a contract. Main criterion of the rules is to decide on how organisations benefit from the project (e.g. how to share the IP, the roles of organisations). Also, duration and funding of the project affect the rules.

As an outcome, organisations exchange (import and export) the knowledge and sources to complement their competencies. If they have good strategies throughout the process, they can import new resources to the organisation. As they gain technical expertise on the field, they can use that to have a competitive advantage and be leader in the market. Moreover, external organisations can use the exploited knowledge and sources to innovate and grow businesses.

\section{The discussion on the case study and the open innovation concept}

We will discuss this case study within two following purposes:

- The significance of case study findings to the open innovation concept

- The potential areas for the future design management studies

Firstly, this study shows that the objective of joint R\&D projects is to convert ideas to the main projects that are ready to commercialise as a next step (van der Meer, 2007). This study reveals that engineers and managers are the subjects of these processes. This research does not reveal what happens inside the organisations in detail. As Piller \& West (2014) emphasises, we also recommend new studies to understand how coupled processes are undertaken internally.

Similar to the literature (Enkel et al., 2009; Laursen \& Salter, 2006; Piller \& West, 2014), the case study reveals that users, suppliers, universities, public and government research institutes and SMEs are members or community of the joint R\&D projects. Piller \& West (2014) state that the locus of innovation can be considered interactive on coupled processes. This study contributed to the base of knowledge by identifying whether this community import or export their knowledge (See The Research Findings).

Impetus for collaboration (Piller \& West, 2014) is a bottom-up division of labour. Furthermore, the joint R\&D project of this case study implements Stage-Gate model aligned with Stage-Gate model of Cooper (2008). Moreover, the activities undertaken in stages (defining, finding participant, collaborating and leveraging) have many similarities with the study of Piller \& West (2008). As they also argue, this study shows that leveraging from the joint R\&D projects is still a challenge that organisations do not fully benefit from the outcome of these projects.

In addition, Sundbo \& Gallouj (2000) emphasise that there are no strict external and internal rules in these processes. This study also shows that rules are mainly defined by the contract done in the beginning of the project. Instruments used for these processes are outlined in the previous chapter, but literature lacks information regarding this aspect. Lastly, in line with the literature (Gasmann \& Enkel, 2004; Kogut, 1988), this research shows that the main outcome of coupled processes is sharing knowledge. There are also other outcomes aligned with the literature (keeping up with technological developments and protecting competitive advantage, complementing the competencies) (Chesbrough, 2003; Enkel et al. 2009; Koschatzky, 2001; Lichtenthaler, 2011). One main challenge is to commercialise joint R\&D projects. 


\section{Conclusion}

The main purpose of this research was to explore how coupled open innovation processes are undertaken in innovation organisations from the perspectives of employees. In addition to the study of Van der Meer (2007) and Piller \& West (2014), the main contribution of this study is observing these processes in a comprehensive way through mapping importing and exporting mechanisms based on AT categories. Moreover, design practice and research can especially take advantage of these findings by analysing the research findings and evaluating recommendations of this paper.

As open innovation is a new field, there are some limitations that should be taken into consideration. These are as following:

- Literature review of this paper mainly covers open innovation literature, whilst design literature has not been reviewed for this research.

- Piller \& West (2014) state that coupled open innovation processes are based on open innovation, user innovation and co-creation. However, this case study findings do not provide information about user innovation and co-creation aspects of these processes.

- The case study is a weak point of this paper because there is almost no example on the literature using the similar methods used for this research (cards, AT). Therefore, authors of this paper have difficulties to design the research, which might affect the reliability of the findings.

- The joint R\&D projects are investigated from the employee perspective of one organisation and this might affect the reliability of the findings.

\section{Recommendations}

Aligned with the significance and limitations of the study, we recommend the following points that future design management studies can explore:

- There is a need for reviewing design management literature to outline the research done so far about open innovation processes.

- This study shows that leveraging from the joint R\&D projects (commercialisation process) is still a challenge and organisations do not fully benefit from the outcome of these projects. Future studies can be focus on commercialising R\&D projects via IP strategies and new business models. For example, design management literature can specifically focus on mapping commercialisation processes and whether design can contribute to these processes.

- Each category of AT might be explored in more detail because there is a lack of information. For example, there is little information about instruments used in coupled open innovation processes. For instance, design research might focus on the instruments to identify the problems and develop new solutions.

- The case study findings do not provide information about user innovation and co-creation aspects of these processes, so the future studies might focus on these aspects.

- This research shows the efficiency of case studies to understand the phenomenon but there is only one case study conducted. Therefore, more case studies can be done to have reliable findings.

- More studies are needed to understand how open innovation is undertaken internally by employees. 
- The research methods (Activity Theory and card) used for this study should be experimented and improved by conducting further case studies.

\section{Implications to Design Practice}

We consider that design practice can help overcome the identified challenges of the coupled open innovation processes. The potential design practice contribution areas might be as following:

- Setting up a consultancy agency that offers design thinking methods for organisations to help them to steer through the open innovation processes

- Designing tools (e.g. set of visual cards) and setting up workshops (cognitive idea generation sessions with partners) to help organisations consciously understand these processes

- Developing business models and services for open innovation processes

- Designing new products and services by identifying the needs of open innovation processes

\section{References}

Barriball, K. L., \& While, A. (1994). Collecting data using a semi-structured interview: A discussion paper. Journal of Advanced Nursing, 19(2), 328-335.

Cash, P., Hicks, B., \& Culley, S. (2015). Activity Theory as a means for multi-scale analysis of the engineering design process: A protocol study of design in practice. Design Studies, 38, 1-32. doi:10.1016/j.destud.2015.02.001

Chatzakis, E. (2015). Maintaining agility: A study of obscure New Product Development practices in small and medium sized manufacturing enterprises to understand how they maintain relevance to their markets. (Doctor of Philosophy), Northumbria University, Newcastle.

Chesbrough, H. (2003). Open Innovation: The new imperative for creating and profiting from technology. Boston, MA: Harvard Business School Press.

Chesbrough, H., \& Bogers, M. (2014). Explicating open innovation: Clarifying an emerging paradigm for understanding innovation. In H. Chesbrough, Vanhaverbeke, W., \& West, J. (Ed.), New frontiers in open innovation (pp. 3-28). New York: Oxford University Press.

Chesbrough, H., Vanhaverbeke, W., \& West, J. (Ed.) (2006). Open Innovation: Researching a new paradigm. New York: Oxford University Press.

Chesbrough, H. W., \& Appleyard, M. M. (2007). Open innovation and strategy. California Management Review, 50(1), 57-76.

Cooper, R. G. (2008). Perspective: The Stage-Gate idea-to-launch process-update, what's new and NexGen systems. Journal of Product Innovation Management, 25(3), 213-232.

Dahlander, L., \& Gann, D. M. (2010). How open in innovation? Research Policy, 39(2010), 699-709. doi:10.1016/j.respol.2010.01.013

Daniels, K., De Chernatony, L., \& Johnson, G. (1995). Validating a method for mapping managers' mental models of competitive industry structures. Human Relations, 48(9), 975-991.

Dodgson, M., Gann, D. M., \& Salter, A. J. (2006). The role of technology in the shift towards open innovation: The case of Protector \& Gamble. R\&D Management, 36(3), 333-346. doi:10.1111/j.1467-9310.2006.00429.x

Engeström, Y. (1987). Learning by expanding: An activity-theoretical approach to developmental research. Helsinki: Orienta-Konsultit.

Engeström, Y. (1993). Developmental studies of work as a testbench of activity theory: The case of primary care medical practice. In S. Chaiklin, \& Lave, J. (Ed.), Undestanding practice: Perspectives on activity and context (Vol. 78, pp. 64-103). Cambridge: Cambridge University Press. 
Engeström, Y., Miettinen, R., \& Punamäki, R. L. (1999). Perspectives on activity theory. Cambridge: Cambridge University Press.

Enkel, E., Gassmann, O., \& Chesbrough, H. (2009). Open R\&D and open innovation: Exploring the phenomenon. R\&D Management, 39(4), 311-316.

Fylan, F. (2005). Semi-structured interviewing. In J. Miles, \& Gilbert, P. (Ed.), A handbook of research methods for clinical and health psychology. Oxford: Oxford University Press.

Gammack, J. G. (1987). Modelling expert knowledge using cognitively compatible structures. Paper presented at the 3rd. International Expert Systems, London.

Gassmann, O. (2006). Opening up the innovation process: Towards an agenda. $R \& D$ Management, 36(3), 223-228.

Gassmann, O., \& Enkel, E. (2004). Towards a theory of open innovation: Three core process archetypes. Paper presented at the R\&D Management Conference.

Gassmann, O., Enkel, E., \& Chesbrough, H. W. . (2010). The future of open innovation. R\&D Management, 40(3), 213-221.

Harrel, M. C., \& Bradley, M. A. (2009). Data collection methods. Semi-structured interviews and focus groups. Santa Monica: RAND Corporation.

Hasan, H., \& Kazlauskas, A. (2014). Activity theory: Who is doing what, why and how. In H. Hasan (Ed.), Being practical with theory: A window into business research (pp. 9-14). Wollongong, Australia: THEORI.

Huizingh, E. K. (2011). Open innovation: State of art and future perspectives. Technovation, 31(1), 29.

King, S., \& Ockels, C. . (2009) Defining small business Innovation. Future of Small Business Series.

Kogut, B. (1988). Joint ventures: Theoretical and empirical perspectives. Strategic Management Journal, 9(4), 319-332.

Koschatzky, K. (2001). Networks in innovation resarch and innovation policy: An introduction. Paper presented at the Innovation Networks. https://link.springer.com/chapter/10.1007/978-3642-57610-2_1

Laursen, K., \& Salter A. (2006). Open for innovation: The role of openness in explaining innovation performance among U.K. manufacturing firms. Strategic Management Journal, 27(2), 131-150.

Lichtenthaler, U. (2011). Open Innovation: Past Research, Current Debates, and Future Directions. Academy of Management Perspectives, 25(1), 75-93.

Macpherson, A., \& Clark, B. (2009). Islands of practice: Conflict and a lack of "Community" in situated learning. Management Learning, 40(5), 551-568.

Normann, R., \& Ramirez, R. (1992). From value chain to value constellation: Designing interactive strategy. Harvard Business Review, 71(4), 65-77.

Piller, F., \& West, J. (2014). Firms, users and innovation: An interactive model of coupled open innovation. In H. Chesbrough, Vanhaverbeke, W., \& West, J. (Ed.), New frontiers in open innovation (pp. 29-49). New York: Oxfors University Press.

Sundbo, J., \& Gallouj, F. (2015). Innovation as a loosely coupled system in services. International Journal of Services Technology and Management, 1(1), 15-36.

Van der Meer, H. (2007). Open innovation - the Dutch treat: Challenges in thinking in business models. Creativtiy and Innovation Management, 16(2), 192-202.

Von Hippel, E. (1988). The sources of innovation. New York: Oxford University Press.

Von Hippel, E. (2005). Democratizing innovation. Cambridge, MA: The MIT Press.

Von Hippel, E. (2010). Open user innovation. In B. H. R. Hall, N. (Ed.), Handbook of the Economics of Innovation (Vol. 1, pp. 411-427): Elsevier.

Vygotsky, L. S. (1978). Mind in society: The development of higher mental process: Harvard University Press.

Waycott, J., Jones. A., \& Scanloon, E. (2005). PDAs as Lifelong Learning Tools: An activity theory based analysis. Learning, Media and Technology, 30(2), 107-130. 
West, J., \& Bogers, M. (2013). Leveraging external sources of innovation: A review of research on open innovation. Journal of Product Innovation Management, 31(4), 814-831.

Wikström, S. (1996). Value creation by company-consumer interaction. Journal of Marketing Management, 12(5), 359-374.

About the Authors:

Yasemin Canik is a PhD researcher in the Institute for Design Innovation at Loughborough University London. Her research is investigating the intersection of the open innovation and design processes specify in the area commercialisation.

Dr Erik Bohemia is the Programme Director in the Institute for Design Innovation at Loughborough University London. He led to completion an AHRC funded project exploring how new digital technologies are affecting and changing knowledge translation in New Product Development and innovation.

Dr Ida Telalbasic is a service design researcher and a lecturer at the Institute for Design Innovation, Loughborough University London. 